\title{
Article \\ The Energetic Aspect of Organic Wastes Addition on Sewage Sludge Anaerobic Digestion: A Laboratory Investigation
}

\author{
Aleksandra Szaja *(D), Agnieszka Montusiewicz and Magdalena Lebiocka $\mathbb{C}$ \\ Faculty of Environmental Engineering, Lublin University of Technology, Nadbystrzycka 40B, \\ 20-618 Lublin, Poland; a.montusiewicz@pollub.pl (A.M.); m.lebiocka@pollub.pl (M.L.) \\ * Correspondence: a.szaja@pollub.pl; Tel.: +48-81-538-40-08; Fax: +48-81-538-19-97
}

check for updates

Citation: Szaja, A.; Montusiewicz, A.; Lebiocka, M. The Energetic Aspect of Organic Wastes Addition on Sewage Sludge Anaerobic Digestion: A Laboratory Investigation. Energies 2021, 14, 6113. https://doi.org/ $10.3390 /$ en14196113

Academic Editors: Javier

Miguel Ochando-Pulido and

Srikanth Vuppala

Received: 13 July 2021

Accepted: 23 September 2021

Published: 25 September 2021

Publisher's Note: MDPI stays neutral with regard to jurisdictional claims in published maps and institutional affiliations.

Copyright: (c) 2021 by the authors. Licensee MDPI, Basel, Switzerland. This article is an open access article distributed under the terms and conditions of the Creative Commons Attribution (CC BY) license (https:// creativecommons.org/licenses/by/ $4.0 /)$.

\begin{abstract}
One of the possibilities to achieve energy neutrality of wastewater treatment plants (WWTPs) is the implementation of the anaerobic co-digestion strategy. However, a key factor in its successful implementation on the technical scale is the application of components with complementary composition to sewage sludge (SS). In the 7resent study, the influence of adding various co-substrates on the energy balance of anaerobic digestion was evaluated. The following organic wastes were used as additional components to SS: organic fraction of municipal solid waste (OFMSW) and distillery spent wash (DW) applied in two- and three-component systems. The experiments were performed in semi-flow anaerobic reactors with the volume of $40 \mathrm{~L}$ under mesophilic conditions $\left(35^{\circ} \mathrm{C}\right)$ at hydraulic retention time (HRT) of 20,18 , and $16 \mathrm{~d}$. The application of substrates to SS resulted in enhancements of methane yields as compared to SS mono-digestion. The statistically significant differences were observed in tertiary mixtures at both HRT of 18 and $16 \mathrm{~d}$. Therein, average values were 0.20 and $0.23 \mathrm{~m}^{3} \mathrm{~kg}^{-1} \mathrm{VS}_{\text {add }}$ at HRT of 18 and $16 \mathrm{~d}$, respectively. Among all co-digestion series, the most beneficial effect on energy balance was found in $20 \% v / v$ DW presence in both two- and three-component systems at HRT of $16 \mathrm{~d}$.
\end{abstract}

Keywords: energy production; biogas; anaerobic digestion; distillery spent wash; organic fraction of municipal solid wastes; energy balance

\section{Introduction}

Currently, one of the greatest challenges facing humanity is the growing demand for energy. The spreading population and depletion of alternative energy resources draw attention to the production of clean energy and force the search for new solutions to improve the efficiency of the available technologies [1,2].

Surprisingly, wastewater treatment plants (WWTPs) are one of the largest energy consumers in settlements. In the United States, the energy consumption of WWTPs is estimated at $3.4 \%$ of the total electricity consumption of the country [3-5]. This fact is related to the necessity to apply high-efficiency technologies to meet the stringent requirements of the wastewater discharged into the environment. Each stage of wastewater and sewage processing has a significant energy demand [4]. Depending on the adopted technology, the electricity consumption at WWTPs varies between $0.2-2.0 \mathrm{kWh}$ for each $\mathrm{m}^{3}$ of treated wastewater [5]. The biological treatment indicates the highest energy consumption reaching up to $71 \%$ [3]. Importantly, wastewater contained a significant amount of organic energy; it is estimated that it is about 9-10 times higher than the energy used for its processing [6]. While many facilities have not paid sufficient attention to energy saving [4,7], the energy potential of the Polish WWTPs is still unemployed; it is estimated that less than $40 \%$ is used [8]. However, the change will shortly be enforced both through legal regulations and the increasing operating costs. Moreover, the last World Climate Summit introduced stricter regulations of greenhouse gas emissions, aiming to achieve net-zero communities and economy [9]. 
Among all treatment stages, anaerobic digestion (AD) allows for the production of alternative energy while contributing to the reduction in greenhouse gas emissions from WWTPs $[9,10]$. AD is a well-recognized technology, in which microorganisms convert organic material in the absence of oxygen into biogas, including mainly carbon dioxide and methane. After purification, this by-product has a wide range of potential applications, including production of heat and electricity in a combined heat and power unit (CHP) [11,12].

Importantly, a properly conducted process allows the generation of additional energy profit and hence constitutes a source of surplus income for WWTPs. This fact is particularly important due to the significant operating costs (estimated at 50\%) associated with SS processing $[13,14]$. Nevertheless, in many cases, the energy generated in the AD process may not cover its demand. Such a situation may be observed in the case of an unfavorable composition of SS or low temperatures in the winter period. In this technology, significant expenditures are related with a heating the feedstock to the adopted temperature (greater for thermophilic conditions) and heat loss through the walls of the digester. These two factors are closely associated with the location of the facility and the season.

Additionally, AD is a complex, multistage, and highly responsive system that depends on various conditions, such as feedstock composition, presence of inhibitors, operating parameters (organic loading rate (OLR), hydraulic retention time (HRT), temperature, as well as reactor configuration). Even minor fluctuations can affect the activity of microorganisms, reducing the amount of generated biogas or event process breakdown [15]. Additionally, $\mathrm{AD}$ of SS as a sole component is characterized by low biogas production, as well as process instability $[16,17]$.

Therefore, the anaerobic co-digestion process (AcoD) is gaining greater importance. This technology involves a simultaneous digestion of two or more substrates with a complementary composition $[18,19]$. Implementation of this strategy can overcome the difficulties related to single substrate digestion, resulting from low organic load, imbalanced $\mathrm{C} / \mathrm{N}$ ratio, lack of micro- and macronutrients, and the presence of $\mathrm{AD}$ inhibitors, such as heavy metals, thus contributing to enhanced growth of a more robust and diverse microbial community [20]. Improving the feedstock composition resulted in the intensification of biogas production, as well as stable process performance. Another factor in favor of applying this method at the existing WWTPs is the employment of the unused biogas potential of the digesters that can reach even 30\% [21]. Importantly, AcoD allows for the conversion of various wastes to biogas instead of disposal at a landfill or application of more advanced methods. Enrichment of feedstock in a valuable agricultural waste often also improves the quality of digestate, allowing for its land application as a fertilizer [11,17].

Currently, due to various benefits, the implementation of AcoD arouses growing interest among scientists and technologists. However, a crucial element in the effective application of AcoD is selection of adequate co-substrate to achieve a synergistic effect. The application of this technology on a technical scale often becomes unsuccessful, mainly due to organic overloading and acidification $[17,22]$. The improvement of biogas production may only be achieved by selection of an appropriate additional component and ensuring proper operating conditions, e.g., dose of co-substrate, temperature, HRT, and OLR. These goals can be realized by conducting research in semi-flow systems. It should be noticed that the commonly applied batch reactors indicate a possibility of using the waste in $\mathrm{AD}$ through specifying its biogas potential. Experiments of this type are preliminary, and often do not correspond to the results obtained in a technical scale [23]. Further, equally important factors to be considered are availability at local market and possible pretreatment costs. For this reason, a long-distance transport should be avoided. Moreover, the energy consumption for preliminary preparation of the substrate should also be included in the energy balance of WWTPs.

In the present work, the influence of adding organic wastes on the energy balance of AD was evaluated. The conducted study consisted of two main parts: lab-scale experiments and energy balance evaluations. The following wastes were applied as additional 
components to SS: organic fraction of municipal solid waste (OFMSW) and distillery spent wash (DW). Two- and three-component mixtures were used in this experiment. The effect of operational parameters, such as volumetric ratio, variable HRT, and OLR on biogas production, was also evaluated. Importantly, the research was conducted in semi-flow reactors with a significant volume $(40 \mathrm{~L})$. The energy balance calculations were performed for the existing digesters based on the results obtained in lab-scale experiments [24].

The novelty of the study involved evaluating the effects of multi-component codigestion of sewage sludge with OFMSW and DW in a semi-flow mesophilic system. Importantly, such extensive research in this field has not been conducted to date. Moreover, energetic aspect of the application of these substrates has not been discussed in the literature. It should be also noticed that most of the studies related to energy balances of WWTPs concerns the improvement of aeration process (biological treatment) [25-27]. Importantly, the evaluation was made for the existing WWTPs; therefore, the presented results can be easily implemented into a technical scale.

\section{Materials and Methods}

\subsection{Selection of Substrates and Its Characteristics}

The study was carried out under the conditions analogous to those on a technical scale; therefore, wet AD, with total solid content below $15 \%$ and mesophilic conditions $\left(35^{\circ} \mathrm{C}\right)$, was applied. SS was used as a main substrate, while OFMSW and DW were applied as additional components. The criteria that were taken into account when selecting co-substrates were their composition (Table 1), the availability on the local market, and the possibility of the intensifying biogas production. The fact that there will be no need to apply advanced pretreatment methods during implementation on a technical scale was also considered.

Table 1. Composition of substrates used in experiments.

\begin{tabular}{ccccc}
\hline \multirow{2}{*}{ Parameter } & Unit & SS & OFMSW & DW \\
\cline { 3 - 5 } & & \multicolumn{2}{c}{ Average Value \pm Standard Deviation } \\
\hline COD & $\mathrm{mg} \mathrm{L}^{-1}$ & $43,528 \pm$ & $33,745 \pm 1709$ & $72,870 \pm 470$ \\
sCOD & $\mathrm{mg} \mathrm{L}^{-1}$ & 2083 & $9672 \pm 1812$ & $38,886 \pm 175$ \\
VFA & $\mathrm{mg} \mathrm{L}^{-1}$ & $1486 \pm$ & $6695 \pm 1200$ & $1449 \pm 261$ \\
pH & & $6.05 \pm$ & $6.7 \pm 0.5$ & $3.45 \pm 0.2$ \\
$\mathrm{ALK}$ & $\mathrm{mg} \mathrm{L}^{-1}$ & $840 \pm$ & $3175 \pm 85$ & - \\
$\mathrm{TS}$ & $\mathrm{g} \mathrm{kg}^{-1}$ & $37.3 \pm$ & $33.8 \pm 2.3$ & $50.4 \pm 4.1$ \\
$\mathrm{VS}$ & $\mathrm{g} \mathrm{kg}^{-1}$ & $28 \pm$ & $22.2 \pm 1.9$ & $46.3 \pm 3.7$ \\
$\mathrm{Ng}_{\mathrm{og}}$ & $\mathrm{mg} \mathrm{L}^{-1}$ & $864 \pm$ & $1392.7 \pm 53$ & $2275 \pm 78$ \\
$\mathrm{~N}_{-} \mathrm{mg} \mathrm{L}_{4}{ }^{+}$ & $\mathrm{mg} \mathrm{L}^{-1}$ & $68.9 \pm$ & $305 \pm 5.2$ & $7.75 \pm 3.5$ \\
$\mathrm{P}_{-} \mathrm{PO}_{4}{ }^{-1}$ & & $112.8 \pm$ & $21.1 \pm 1.9$ & $316.5 \pm 33$ \\
\hline
\end{tabular}

The main substrate SS indicated a low buffering capacity, unfavorable $\mathrm{C} / \mathrm{N}$ ratio, and low concentration of soluble chemical oxygen demand (sCOD) (Table 1). It is also characterized by a significant content of heavy metals, pharmaceuticals as well as pathogens. Taking these facts into consideration, SS should be co-digested with the wastes with a higher $\mathrm{C} / \mathrm{N}$ ratio, rich in organic matter and macro- and microelements that can simulate the methanogenic activity.

Therefore, OFMSW was chosen as an additional component to SS. This residual indicated significant volatile fatty acids (VFA) and alkalinity (ALK) content among all substrates used in this study. It was also characterized by a significant content of biodegradable organic matter. Nevertheless, as compared to SS, it has a higher concentration of total and ammonium nitrogen that may favor ammonia inhibition [28].

DW was used as a second complementary component to SS. This liquid by-product from a distillery industry was characterized by a significant content of easily biodegradable organic matter as well as beneficial C/N ratio. Moreover, the presence of vitamins, mineral salts, and amino acids might stimulate the methanogenic microorganisms, hence 
enhancing the biogas production [29,30]. The application of this substrate may also result in the dilution of undesired compounds such as heavy metals, pharmaceuticals, and/or pathogens typically present in SS [16]. It should also be noted that DW had a significant temperature of $85^{\circ} \mathrm{C}$. This factor is particularly beneficial in terms of improving the energy efficiency of AD. It could reduce the energy requirements for feedstock heating to mesophilic temperatures, contributing to obtaining greater energy gains. In turn, an unfavorable factor that may cause an unstable process performance is its low $\mathrm{pH}$ that could lead to the accumulation of VFA [28]. Importantly, both co-substrates indicated a significant biogas/methane potential as compared to SS [22]. In addition, these components were available in large quantities throughout the year.

However, each of the mentioned residues showed deficiencies; according to previous studies, their mono-digestion often resulted in poor process performance or indicated technological difficulties in AD. Moreover, their effective management is still a serious environmental problem [31-33]. However, their biogas potential may be used in AcoD, while the selection of appropriate process conditions is a crucial element to achieve a synergetic effect.

\subsection{Preparation of Substrates}

The main substrate (SS) was taken from the Puławy WWTP (Poland), that serves a population of approx. 80,000 P.E (population equivalent). It was a mixture of thickened sludge taken from the gravity thickener and belt press. The volumetric ratio of these was 60:40 v/v (primary: waste sludge). These samples were taken once a week; under laboratory conditions, they were homogenized and stored at a temperature of $4{ }^{\circ} \mathrm{C}$. As is presented in Table 1, the SS characteristic indicated a considerable difference throughout experiments. This fact was related with the variable composition of the wastewater discharged to WWTP. For this reason, a separate control series (R 1.1, R 1.3, R 2.1, R 3.1, and R 3.3) was planned for each experiment.

OFMSW was applied as the first additional component to SS. This sample originated from waste treatment plant employing the BTA technology. It was a solid fraction diluted by the landfill leachate discharged from the hydrocyclone. OFMSW was taken three times for each experiment, separately. This sample after homogenization was frozen at $-25^{\circ} \mathrm{C}$. This procedure allowed keeping unchanged substrate composition during the experiments. DW, as the second additional component to SS, was collected from a distillery located at Żyrzyn (Poland) that used a rye or barley for ethanol production. Similar to the preparation of the first co-substrate, this component was homogenized after sampling and then frozen.

Before supplying the laboratory digesters, the co-substrates were thawed and added in an appropriate amount according to operational set-up to the feedstock (Table 2).

Table 2. Operational conditions used in experiments.

\begin{tabular}{|c|c|c|c|c|c|c|c|c|}
\hline \multirow{3}{*}{ Run } & \multirow{3}{*}{$\begin{array}{l}\text { Feedstock } \\
\text { Composition }\end{array}$} & \multicolumn{3}{|c|}{ Component Volume } & \multirow{3}{*}{$\begin{array}{l}\text { Volumetric Ratio } \\
\text { SS:OFMSW:DW }\end{array}$} & \multirow{3}{*}{$\begin{array}{c}\text { HRT } \\
\text { d }\end{array}$} & \multicolumn{2}{|r|}{ OLR } \\
\hline & & \multirow{2}{*}{$\begin{array}{c}\text { SS } \\
\mathrm{L}\end{array}$} & \multirow{2}{*}{$\frac{\text { OFMSW }}{\mathrm{L}}$} & \multirow{2}{*}{$\frac{\mathrm{DW}}{\mathrm{L}}$} & & & Avg *. & Upp./low. 95\% Mean ** \\
\hline & & & & & & & & kg vs. $\mathrm{m}^{-3} \mathrm{~d}^{-1}$ \\
\hline \multicolumn{9}{|c|}{ Experiment 1} \\
\hline R 1.1 & SS (control) & 2.0 & - & & 100:0:0 & & 1.37 & $1.23 / 1.51$ \\
\hline $\mathrm{R} 1.2$ & SS + OFMSW & 1.5 & 0.5 & - & $75: 25: 0$ & & 1.17 & $1.07 / 1.27$ \\
\hline $\mathrm{R} 1.3$ & SS (control) & 2.0 & - & & 100:0:0 & 20 & 1.37 & $1.3 / 1.44$ \\
\hline $\mathrm{R} 1.4$ & SS + OFMSW & 1.4 & 0.6 & - & $70: 30: 0$ & & 1.08 & $1.03 / 1.13$ \\
\hline \multicolumn{9}{|c|}{ Experiment 2} \\
\hline R 2.1 & SS (control) & 2.0 & - & & 100:0:0 & 20 & 1.43 & $1.42 / 1.44$ \\
\hline $\mathrm{R} 2.2$ & SS + DW & 2.0 & - & 0.2 & $91: 0: 9$ & 18 & 1.78 & $1.75 / 1.81$ \\
\hline R 2.3 & $\mathrm{SS}+\mathrm{DW}$ & 2.0 & - & 0.5 & $80: 0: 20$ & 16 & 2.23 & $2.18 / 2.28$ \\
\hline \multicolumn{9}{|c|}{ Experiment 3} \\
\hline R 3.1 & SS (control) & 2.0 & - & & 100:0:0 & 20 & 1.44 & $1.36 / 1,52$ \\
\hline R 3.2 & $\mathrm{SS}+\mathrm{OFMSW}+\mathrm{DW}$ & 1.5 & 0.5 & 0.2 & $68: 23: 9$ & 18 & 1.58 & $1.52 / 1.64$ \\
\hline R 3.3 & SS (control) & 2.0 & - & & 100:0:0 & 20 & 1.42 & $1.31 / 1.53$ \\
\hline R 3.4 & $\mathrm{SS}+\mathrm{OFMSW}+\mathrm{DW}$ & 1.5 & 0.5 & 0.5 & $60: 20: 20$ & 16 & 1.79 & $1.68 / 1.9$ \\
\hline
\end{tabular}

* average value, ${ }^{* *}$ upper/lower $95 \%$ mean. 


\subsection{Operational Conditions and Laboratory Installation}

Three main experiments were performed, differing both in HRT and feedstock composition. The first two involved two-component AcoD. Therein, SS was used as a main substrate, while OFMSW or DW were chosen as additional components. In the last experiment, a mixture of all three substrates was used; however, SS still remained the dominant component. Detailed operational conditions are presented in Table 2. In order to evaluate the effect of co-substrates on the $\mathrm{AD}$ process, a separate control series was provided in each experiment, in which the mono-digestion of SS was performed.

Each series lasted a total of 90 days, of which the first 30 days was the adaptation phase, while the following 60 days was the period for measurements and data collection.

In order to evaluate methane yields, the experiments were performed in laboratory continuous stirred-tank reactors (CSTR) with the volume of $40 \mathrm{~L}$. The reactors had a conicalcylindrical shape typical for the digesters found in Polish WWTPs (Figure 1). In order to maintain a mesophilic temperature, each CSTR was kept in a heating jacket. Mixing was carried out by means of a slow-speed mechanical mixer with a rotational speed of $50 \mathrm{~min}^{-1}$. A semi-continuous system was used, in which the substrate was supplied daily with a simultaneous discharge of an identical volume of digestate. The dosing of the substrates was carried out by means of a peristaltic pump from the feeding tank. In turn, the digested sludge was collected by gravity from the stub equipped with a shut-off valve located in lower cone and directed to the waste tank.

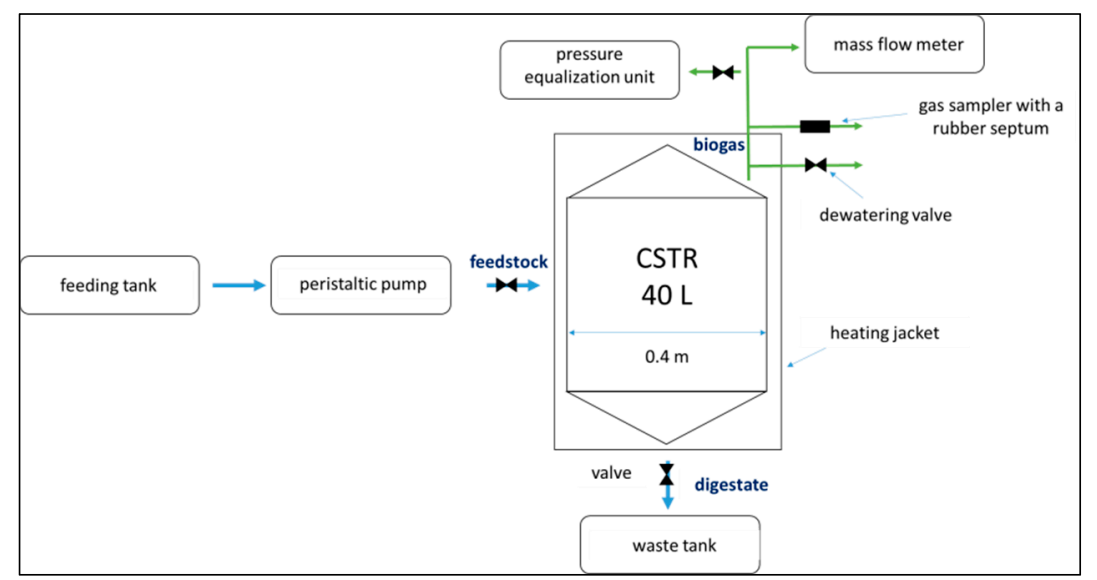

Figure 1. The scheme of laboratory installation.

An inoculum for the CSTRs originated from the mesophilic digester with active volume of $2500 \mathrm{~m}^{3}$ operated at HRT of $25 \mathrm{~d}$, located at Puławy WWTP. The adaptation of this sample occurred after $30 \mathrm{~d}$.

Both the volume and composition of biogas were monitored during the experiments; a gaseous installation was intended for this purpose. This system included pipelines, gas and dewatering valves, a gas sampler with a rubber septum for sampling, a pressure equalization unit, and a mass flow meter.

\subsection{Energy Balance Evaluation}

The energy balance was performed for more unfavorable conditions-winter season. In this study, the evaluation was made for the digester operating at Puławy WWTP; the outside air temperature for this location was assumed to be $-20^{\circ} \mathrm{C}\left(\mathrm{T}_{\text {air }}\right)$. Moreover, to evaluate the energy balance, mesophilic conditions were applied $\left(\mathrm{T}_{\mathrm{AD}}=35^{\circ} \mathrm{C}\right)$. It should be noticed that the application of certain substrates reduced the energy requirements for feedstock heating $\left(\mathrm{Q}_{\mathrm{HF}}\right)$. For calculations, it was assumed that the $\mathrm{SS}$ temperature was $8^{\circ} \mathrm{C}$; importantly, implementation of OFMSW did not affect the feedstock temperature $\left(\mathrm{T}_{\text {feed }}\right)$. In turn, the application of DW would increase the feedstock temperature from 8 to 10 and $13^{\circ} \mathrm{C}$ (depending on the share in the mixture). In this evaluation, it was assumed that this 
additional component would be added after its delivery from the distillery, it would not be stored.

The thermal energy theoretically obtained from the combustion of methane $\left(\mathrm{Q}_{\mathrm{T}}\right)$ was evaluated based on methane yields $\left(\mathrm{Y}_{\mathrm{m}}\right)$ achieved in the present study (Table 3). In order to evaluate the heat loss through the walls of the digester $\left(\mathrm{Q}_{\mathrm{H}}^{\mathrm{L}}\right)$, the reactor of volume $2500 \mathrm{~m}^{3}$ and diameter (D) of $15 \mathrm{~m}$ were assumed. The HRT values were adopted from the operational set-up used under laboratory experiments (Table 2). The profit of thermal energy $(\mathrm{P})$ was calculated as difference between the thermal energy obtained and $\mathrm{AD}\left(\mathrm{Q}_{\mathrm{T}}\right)$ and its demand $\left(\mathrm{Q}_{\mathrm{D}}\right)$.

Table 3. Input parameters to evaluate energy balance $\left({ }^{*}\right.$ average value and $95 \%$ confidence limits are given).

\begin{tabular}{|c|c|c|c|c|c|c|c|c|c|c|c|c|}
\hline Parameter & Unit & R 1.1 & R 1.2 & R 1.3 & R 1.4 & R 2.1 & R 2.2 & R 2.3 & R 3.1 & R 3.2 & R 3.3 & R 3.4 \\
\hline VS & $\mathrm{g} \mathrm{kg}^{-1}$ & 27.4 & 23.3 & 27.5 & 21.5 & 28.5 & 32.3 & 35.7 & 28.7 & 28.8 & 28.4 & 28.7 \\
\hline $\begin{array}{c}\text { Feedstock } \\
\text { density }\end{array}$ & $\mathrm{kg} \mathrm{m}^{-3}$ & 976 & 996.6 & 977 & 993.6 & 1001.5 & 995.9 & 993.4 & 989.8 & 985.1 & 991.4 & 983.4 \\
\hline $\mathrm{L}_{\mathrm{VS}}$ & $\mathrm{kg} \mathrm{d}^{-1}$ & 3342.8 & 2902.6 & 3358.4 & 2670.3 & 3567.8 & 4423.0 & 5319.7 & 3550.9 & 3901 & 3519.5 & 4233.5 \\
\hline$Y_{m}$ * & $\begin{array}{c}\mathrm{m}^{3} \mathrm{CH}_{4} \\
\mathrm{~kg}^{-1} \\
\mathrm{VS}_{\text {add }}\end{array}$ & $\begin{array}{c}0.23 \\
\pm \\
0.03\end{array}$ & $\begin{array}{c}0.29 \\
\pm \\
0.087\end{array}$ & $\begin{array}{c}0.22 \\
\pm \\
0.04\end{array}$ & $\begin{array}{c}0.26 \\
\pm \\
0.061\end{array}$ & $\begin{array}{c}0.19 \\
\pm \\
0.030\end{array}$ & $\begin{array}{c}0.2 \\
\pm \\
0.018\end{array}$ & $\begin{array}{c}0.2 \\
\pm \\
0.031\end{array}$ & $\begin{array}{c}0.17 \\
\pm \\
0.024\end{array}$ & $\begin{array}{c}0.23 \\
\pm \\
0.032\end{array}$ & $\begin{array}{c}0.15 \\
\pm \\
0.018\end{array}$ & $\begin{array}{c}0.2 \\
\pm \\
0.031\end{array}$ \\
\hline $\begin{array}{l}\text { Daily } \\
\text { methane } \\
\text { production }\end{array}$ & $\begin{array}{c}\mathrm{m}^{3} \mathrm{CH}_{4} \\
\mathrm{~d}^{-1}\end{array}$ & 768.8 & 841.8 & 738.8 & 694.3 & 677.9 & 884.6 & 1063.9 & 603.7 & 897.2 & 527.9 & 846.7 \\
\hline $\begin{array}{c}\mathrm{T}_{\text {feed }} \\
\mathrm{V}_{\mathrm{os}}\end{array}$ & $\begin{array}{c}{ }^{\circ} \mathrm{C} \\
\mathrm{m}^{3} \mathrm{~d}^{-1}\end{array}$ & $\begin{array}{c}8 \\
125\end{array}$ & $\begin{array}{c}8 \\
125\end{array}$ & $\begin{array}{c}8 \\
125\end{array}$ & $\begin{array}{c}8 \\
125\end{array}$ & $\begin{array}{c}8 \\
125\end{array}$ & $\begin{array}{c}10 \\
137.5\end{array}$ & $\begin{array}{c}13 \\
150\end{array}$ & $\begin{array}{c}8 \\
125\end{array}$ & $\begin{array}{c}10 \\
138.5\end{array}$ & $\begin{array}{c}8 \\
125\end{array}$ & $\begin{array}{c}13 \\
150\end{array}$ \\
\hline
\end{tabular}

For the energy production at WWTP, the commonly utilized combined heat and power system/unit (CHP) was adopted. Thermal and electric efficiencies were assumed at 0.43 and 0.38 , respectively. The following formulas were used:

$$
\begin{gathered}
\mathrm{Q}_{\mathrm{CH} 4}=\left(\mathrm{Y}_{\mathrm{m}} \times \mathrm{L}_{\mathrm{VS}}\right), \mathrm{m}^{3} \mathrm{CH}_{4} \mathrm{~d}^{-1} \\
\mathrm{Q}_{\mathrm{T}}=\mathrm{Q}_{\mathrm{CH} 4} \times \mathrm{Q}_{\mathrm{i}}, \mathrm{MJ} \mathrm{d}^{-1} \\
\mathrm{Q}_{\mathrm{HL}}=24 \times\left(\mathrm{T}_{\mathrm{AD}}-\mathrm{T}_{\mathrm{air}}\right) \times \mathrm{U} \times \mathrm{A}, \mathrm{kJ} \mathrm{d}^{-1} \\
\mathrm{Q}_{\mathrm{HF}}=\mathrm{V}_{\mathrm{os}} \times\left(\mathrm{T}_{\mathrm{AD}}-\mathrm{T}_{\mathrm{feed}}\right) \times \mathrm{C}_{\mathrm{SS}}, \mathrm{kJ} \mathrm{d}^{-1} \\
\mathrm{~A}=3.17 \times \mathrm{D}^{2}, \mathrm{~m}^{2} \\
\mathrm{Q}_{\mathrm{D}}=1.1 \times\left(\mathrm{Q}_{\mathrm{HL}}+\mathrm{Q}_{\mathrm{HD}}\right), \mathrm{kJ} \mathrm{d}^{-1} \\
\mathrm{P}=\mathrm{Q}_{\mathrm{T}}-\mathrm{Q}_{\mathrm{D}}, \mathrm{kJ} \mathrm{d} \mathrm{d}^{-1} \\
\mathrm{E}_{\mathrm{d}}=\mathrm{Q}_{\mathrm{CH} 4} \times \mathrm{Q}_{\mathrm{ie}}, \mathrm{kWh} \mathrm{d}^{-1} \\
\mathrm{~N}_{\mathrm{t} / \mathrm{e}}=\left(\mathrm{Q}_{\mathrm{CH} 4} / 24\right) \times \mathrm{Q}_{\mathrm{ie}} \times \eta_{\mathrm{t} / \mathrm{e}}, \mathrm{kW}
\end{gathered}
$$

where $\mathrm{L}_{\mathrm{VS}}$ - the VS load in the feedstock, $\mathrm{kg} \mathrm{VS} \mathrm{d}^{-1}$ (Table 2); $\mathrm{Q}_{\mathrm{i}}$ - the heating value of methane $\mathrm{MJ} \mathrm{m}^{-3}$ (35.8 $\left.\mathrm{MJ} \mathrm{m}^{-3}\right) ; \mathrm{V}_{\text {os }}$-daily feedstock flow rate $\mathrm{m}^{3} \mathrm{~d}^{-1}$ (Table 2); $\mathrm{U}$ the heat loss coefficient by permeation through the walls of the digester, $\mathrm{kJ} \mathrm{m}^{2} \mathrm{~h}^{-1} \mathrm{~K}^{-1}$ $\left(4.0 \mathrm{~kJ} \mathrm{~m}^{2} \mathrm{~h}^{-1} \mathrm{~K}^{-1}\right)$; $\mathrm{C}_{\mathrm{SS}}$ - the specific heat of sewage sludge, $\mathrm{kJ} \mathrm{m}^{-3} \mathrm{~K}^{-1}\left(4200 \mathrm{~kJ} \mathrm{~m}^{-3}\right.$ $\left.\mathrm{K}^{-1}\right)$; D-the diameter of the cylindrical part of the digester $(15 \mathrm{~m}), \mathrm{m}$; Ed-daily energy production, $\mathrm{kWh} \mathrm{d}^{-1}$; A - the surface of the digester walls, $\mathrm{m}^{2}$; and $\mathrm{N}_{\mathrm{t} / \mathrm{e}}$ - the theoretical electric/thermal power production, $\mathrm{kW}\left(\eta_{\mathrm{t}}=0.43, \eta_{\mathrm{e}}=0.38\right)$.

\subsection{Analytical Methods and Statistical Analysis}

The same parameters were controlled in all substrates: the total chemical oxygen demand (COD), sCOD, total solids (TS), volatile solids (VS), total nitrogen (TN) and total phosphorus (TP), VFA, ALK, ammonia nitrogen $\left(\mathrm{NH}_{4}{ }^{+}-\mathrm{N}\right)$ and orthophosphate phosphorus $\left(\mathrm{PO}_{4}{ }^{3-}-\mathrm{P}\right)$, and $\mathrm{pH}$ level. Total and volatile solids were controlled based 
on the procedure presented in the Standard Methods for the Examination of Water and Wastewater [34]. In turn, COD, sCOD, TN, TP, VFA, ALK, $\mathrm{NH}_{4}{ }^{+}-\mathrm{N}$, as well as $\mathrm{PO}_{4}{ }^{3-}-\mathrm{P}$ were monitored using Hach Lange UV-VIS DR 5000 involving cuvette tests. Additionally, a HQ 40D Hach-Lange millimeter $\mathrm{pH}$ meter was applied in this study. The composition of feedstock was monitored one a week, after its delivery to the laboratory, while the characteristic of digestate were analyzed twice weekly. The samples of OFMSW and DW were examined once after collection.

The biogas composition was controlled by the means of a ThermoTrace GC-Ultra gas chromatograph (Thermo Fisher Scientific, Milan, Italy). It was equipped with a conductivity detector fitted with divinylbenzene (DVB) packed columns (RTQ-Bond). The parameters used for the analysis were $50{ }^{\circ} \mathrm{C}$ for the injector and $100{ }^{\circ} \mathrm{C}$ for the detector. Helium with a flux rate of $1.5 \mathrm{~cm}^{3} \cdot \mathrm{min}^{-1}$ was used as a carrier gas. For peak areas analysis, a CHROM-CARD program was applied. In turn, the biogas volume of generated biogas was controlled every day; an Aalborg (Orangeburg, NY, USA) digital mass flow meter was applied for this purpose. While the VS content and biogas composition were performed in triplicate. In this study, differences were assumed to be statistically significant at $p<0.05$.

\section{Results and Discussion}

As is shown in Table 3, the introduction of OFMSW resulted in an improvement of methane yield by approx. 26 and $18 \%$ in R 1.2 and R 1.4., respectively, as compared to SS mono-digestion. More beneficial results were found at lower substrate dose of $25 \% v / v$.

However, the observed differences were no of statistical significance. In the present study, comparable methane yields to those presented in the literature were achieved. A key factor in an effective AcoD of these additional components is optimization of the substrate mixing ratio. Typically, the proportion of 25:75 v/v (OFMSW:SS) is applied. Therein, at mesophilic temperature, the methane yield varied between 0.17 to $0.439 \mathrm{~m}^{3} \mathrm{CH}_{4} \mathrm{~kg}^{-1} \mathrm{VS}_{\text {add }}$, depending on the adopted operational conditions [35]. The achieved increases in the presence of OFMSW resulted from supplying the feedstock with easily biodegradable organic matter. It should be noticed that in experiment 1 the constant HRT of $20 \mathrm{~d}$ was adopted.

Importantly, in all series in experiment 1, the obtained thermal energy will completely cover the total thermal demand of the digester (Figure 2).

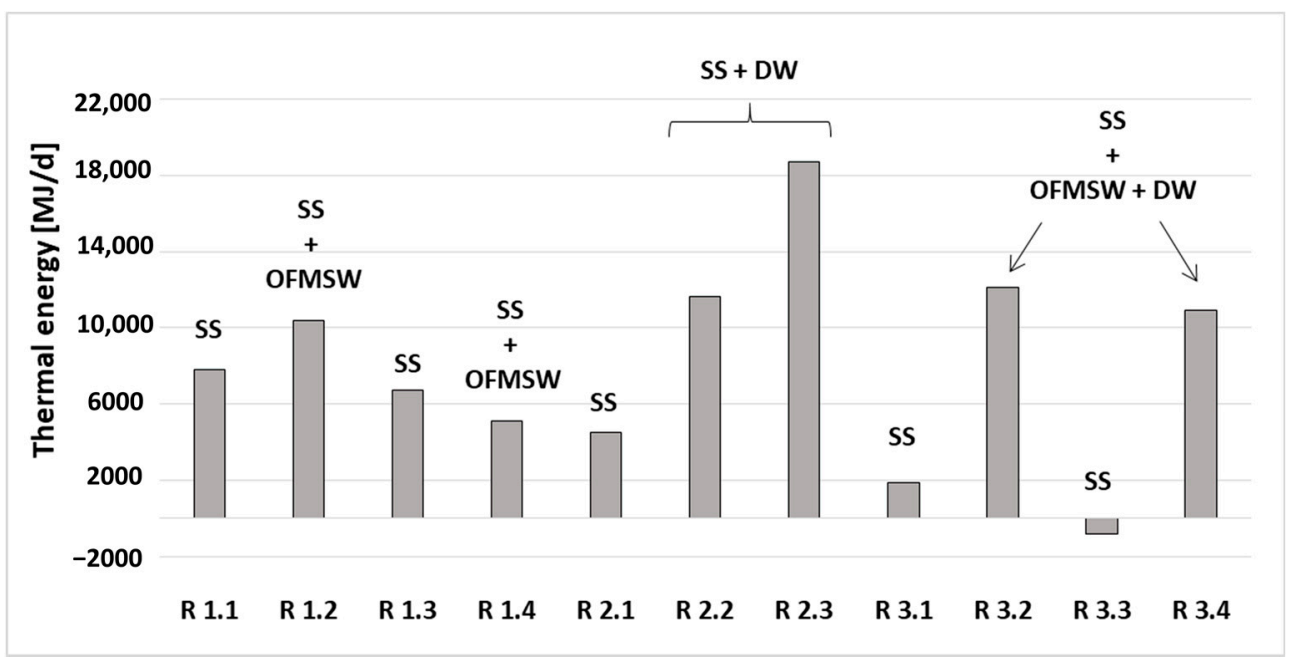

Figure 2. Profit of thermal energy in experiments.

In the presence of $25 \%$ OFMSW (R 1.2 ), the thermal energy was enhanced by $34 \%$ as compared to sewage sludge mono-digestion (R 1.1). A different trend occurred with a higher dose of the substrate (30\% $v / v$ of OFMSW). Therein, a reduction by approx. $24 \%$ was found in comparison to SS mono-digestion. Regarding the thermal and electric power 
productions, again the beneficial effect was observed in the case of a minor dose of the co-substrate $(25 \% v / v$ of OFMSW).

The profit of theoretic thermal and electric power productions was enhanced by $9.5 \%$ as compared to SS mono-digestion. In turn, the supplementation of feedstock with 30\% $v / v$ of OFMSW resulted in $6 \%$ reduction in relation to SS (Figure 3 ).

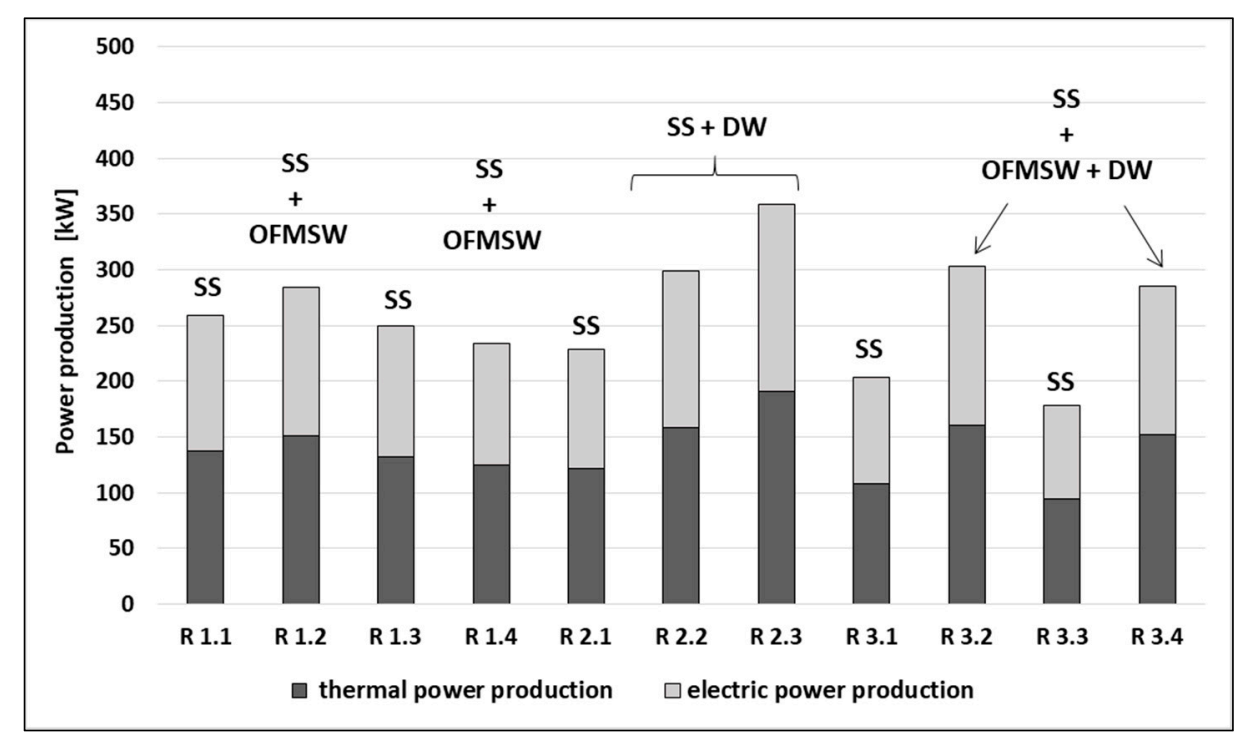

Figure 3. Theoretical thermal/electric power productions in experiments.

Regarding the daily energy production, the average values in co-digestion series were 8418 and $6943 \mathrm{kWh} \mathrm{d}^{-1}$, in the presence of 25 and 30\% v/v of OFMSW, respectively. Comparable results were obtained in control reactors: 7688 and $7388 \mathrm{kWh} \mathrm{d}^{-1}$ in $\mathrm{R} 1.2$ and R 1.3., respectively.

The observed decreases in the presence of 30\% v/v OFMSW might be caused by a significant content of VFA in feedstock that may result in a minor process inhibition. An accumulation of VFA reactor leads to reduction in $\mathrm{pH}$ that may adversely affect the methanogenic activity [15]. Additionally, OFMSW often contains toxic substances such as heavy metals and phthalates that may also inhibit the AD process [35,36]. However, especially in this case, the study should be continued. More thorough research should be conducted. Particularly, amicrobial community analysis should be performed [37]. It should be noted that, in this series (R 1.4), a low VS content was observed, which also influenced the achieved results. Nevertheless, the profit of thermal energy was still observed; however, it was the lowest among all series in experiment 1 . For this reason, the application of 30\% OFMSW should not be considered for implementation into a technical scale. However, the authors would like to point out that one of the possibilities to overcome the drawback of this substrate is its pretreatment $[33,37,38]$.

In the case of DW, a minor growth of methane yields was observed. As compared to SS mono-digestion, this parameter was enhanced by $5 \%$, regardless of the dose of this substrate. In the study performed by Ripoll [39], DW from sherry-wine distillery was applied as an additional component to SS. Therein, the application of this by-product improved the biomethane production as compared to SS, the values between $0.210-0.225 \mathrm{~m}^{3} \mathrm{CH}_{4} \mathrm{~kg}^{-1} \mathrm{VS}_{\text {add }}$ were observed. However, this research was conducted in batch reactors and the substrate dose was higher $(25-75 \% v / v)$. The authors attributed the observed enhancements to an enrichment of the Archaea group, particularly aceticlastic methanogens in co-digestion series. This fact is closely related with DW composition and the presence of nutrients and various microelements such as iron, zinc, copper, manganese, boron, and molybdenum, as well as vitamins [40].

It should be pointed out that much higher thermal energy profit was found in the presence of this co-substrate. In comparison to control, the enhancement by 160 and 312\% 
occurred in the presence of 9 and $20 \% v / v$ of DW, respectively (Figure 2). In turn, the profit of theoretic thermal and electric power productions was improved by 30 and 57\% in the presence of 9 and $20 \% v / v$ of DW (compared to SS mono-digestion) (Figure 3). In co-digestion runs, significant values of daily energy production were found, for $9 \% v / v$ of DW this parameter reached $8846 \mathrm{kWh} \mathrm{d}^{-1}$. The major power production corresponded to the highest DW dose; therein, it reached $10,639 \mathrm{kWh} \mathrm{d}^{-1}$. The SS mono-digestion resulted in minor daily energy production of $6779 \mathrm{kWh} \mathrm{d}^{-1}$.

The main reason of the achieved improvements was an increased temperature of this waste. This fact caused the reduction in the thermal energy required for heating the feedstock. During the implementation of AcoD, the application of substrates characterized by an increased temperature in comparison to SS should be also considered. This group includes mainly the wastes from the agro-food industry, e.g., cheese whey and by-products from breweries and distilleries. However, particular attention should be paid to the location of the company and availability of substrates. In the case of long storage of the substrate in a WWTP or company, the influence of this factor should be neglected.

Importantly, the more favorable results were achieved at shortened HRT of $16 \mathrm{~d}$ and statistically increased OLR (Table 2). It is confirmed that an improved OLR enhances the microbial activity that resulted in increased biogas production, as well as reduced energy demand for heating [41]. Additionally, for the industrial applications of this technology, a reduced HRT and increased OLR are strongly recommended due to the possibility of using the unemployment biogas potential of digesters. Moreover, according to Di Maria [42] the short HRT enhances net electrical energy production in AD [15]. In turn, an excessive reduction may result in washout of microbes, and thus leads to a failure of AD [43].

In experiment 3, the three-component AcoD was performed. In this case, a beneficial influence of co-substrate application was observed. It should be noticed that, in the case of an unfavorable composition of SS, its mono-digestion resulted in a low methane yield (R 3.1 and R 3.3) (Table 3). Therefore, the energy generated from biogas may not fully cover the total thermal energy demand in a winter period (R 3.3). In turn, in both co-digestion series, a substantial growth of methane yield occurred. The statistically significant improvements of 35 and 33\% were found at both HRT of 18 and $16 \mathrm{~d}$, respectively. Both the high values of methane production and increased temperature of feedstock caused by DW use resulted in a generation of significant profit of the thermal energy (Figure 2)

The enhancements of 6- and 12-fold were found at HRT of 18 and $16 \mathrm{~d}$, respectively. In turn, the theoretical electric and thermal power productions were increased by approx. 49 (R 3.2) and 60\% (R 3.4), as compared to the control series. As previously, more favorable results were obtained at shortest HRT. It should be noticed that the daily energy production was also enhanced, reaching 8972 and $8467 \mathrm{kWhd}^{-1}$ at HRT of 18 and $16 \mathrm{~d}$, respectively. The SS mono-digestion resulted in minor productions of 6037 and $5279 \mathrm{kWhd}^{-1}$.

Such beneficial results observed in three-component AcoD regarding the methane yield and energy balance were a consequence of applying the substrates that considerably improved the feedstock composition. Both OFMSW and DW provided a significant content of biodegradable organic matter. Additionally, the utilization of these complementary components allowed us to supplement the deficiencies of each type of waste, resulting in synergistic effects. OFMSW ensured a necessary buffering capacity, reducing in this way the negative impact of DW. In turn, DW limited the adverse effect of high VFA content presented in OFMSW. This additional component also contributed various micro- and macroelements such as vitamins from the B-group that may stimulate the methanogenic activity. However, it should be highlighted that research should be continued in terms of a microbiological community [44], process stability [45], and digestate composition [46]. Only such a holistic approach will allow for the examination of the influence of the addition of substrates on the AD process. Currently, there are not many studies of three-component AcoD. However, the supply of a third substrate can significantly improve the AD efficiency. Therefore, this technology seems to be more beneficial than applying advanced 
pre-treatment methods. The implementation of this strategy does not require a significant investment or maintenance costs.

In three-component mixtures, the SS was co-digested with OFMSW and grease trap sludge [47], in this work, substantial methane yields of $0.259-327 \mathrm{~m}^{3} \mathrm{CH}_{4} \mathrm{~kg}^{-1} \mathrm{VS}_{\text {add }}$ were found, while for SSmono-digestion it was only $0.146 \mathrm{~m}^{3} \mathrm{CH}_{4} \mathrm{~kg}^{-1} \mathrm{VS}_{\text {add }}$. Additionally, the performed energy balance indicated that the utilization of these substrates led to achieving $125 \%$ higher electric power production. In turn, the application of acid cheese whey and brewery spent grain to SS resulted in an improvement of methane yields, with average values of $0.26-0.28 \mathrm{~m}^{3} \mathrm{CH}_{4} \mathrm{~kg}^{-1} \mathrm{VS}_{\text {add }}$. In this case, the implementation of these substrates at HRT of $16.7 \mathrm{~d}$ increased the theoretical electric/thermal power production by $133 \%$ as compared to SS mono-digestion [48].

\section{Conclusions}

The implementation of AcoD in both two and three-component systems resulted in enhancements of methane yields as compared to SS mono-digestion. In turn, the statistically significant differences were observed in tertiary mixtures; the increases of 35 and $33 \%$ were observed at HRT of 18 and $16 \mathrm{~d}$, respectively.

An improvement in the energy balance of the $\mathrm{AD}$ was noted in the presence of cosubstrates. The exception was the series with the highest dose of OFMSW $(30 \% v / v)$ at HRT of $20 \mathrm{~d}$; therein the decreases in comparison to SS mono-digestion were found. Therefore, this co-digestion is not recommended for implementation into a technical scale.

Among all co-digestion series, the most beneficial results were found in the presence of $20 \% v / v$ DW in both two- and three-component systems at HRT of $16 \mathrm{~d}$. The application of this co-substrate in tertiary mixtures overcame the drawbacks of the OFMSW and SS co-digestion. The observed enhancements resulted from the DW composition, its increased temperature, and high values of methane production. Importantly, the generated energy profit may be applied at WWTP, contributing to achieving energy neutrality of the facility. In turn, its surplus may be sold to an external recipient, becoming a source of additional income for the WWTPs. Moreover, the implementation of AcoD allowed for the employment of energy potential of both DW and OFMSW, thus allowing for the management of these two wastes, the effective disposal of which is still a serious environmental problem.

However, it should be noted that the conducted study is preliminary and should be continued in the aspect of process performance. Nevertheless, the obtained results indicated the possibility of using these substrates in co-digestion with SS. Moreover, the established operational conditions, such as substrate dose, HRT, and OLR, allow for easy implementation into technical scale.

Author Contributions: Conceptualization, A.M.; Formal analysis, A.M. and M.L., Funding acquisition, A.M. and A.S.; Investigation, A.M., A.S. and M.L., Methodology, A.M., A.S. and M.L.; Project administration, A.M.; Resources, A.M. and M.L.; Software, A.S. and M.L.; Supervision, A.M. and A.S.; Validation, A.M. and M.L.; Visualization, A.S. and M.L.; Writing-Original draft. A.M. and A.S.; and Writing-Review and editing, A.S. and M.L. All authors have read and agreed to the published version of the manuscript.

Funding: This research was funded by the Polish Ministry of Science and Higher Education [research funding FD-20/IS-6/036, FD-20/IS-6/023].

Institutional Review Board Statement: Not applicable.

Informed Consent Statement: Not applicable.

Data Availability Statement: The data presented in this study are available on request from the corresponding author. The data are not publicly available due to fund requirements.

Conflicts of Interest: The authors declare no conflict of interest. 


\section{References}

1. Kainthola, J.; Kalamdhad, S.A.; Goud, V.V. A review on enhanced biogas production from anaerobic digestion of lignocellulosic biomass by different enhancement techniques. Process. Biochem. 2019, 84, 81-90. [CrossRef]

2. Campana, P.-E.; Mainardis, M.; Moretti, A.; Cottes, M. 100\% renewable wastewater treatment plants: Techno-economic assessment using a modelling and optimization approach. Energy Convers. Manag. 2021, 239, 114214. [CrossRef]

3. Panepinto, D.; Fiore, S.; Zappone, M.; Genon, G.; Meucci, L. Evaluation of the energy efficiency of a large wastewater treatment plant in Italy. Appl. Energy 2016, 161, 404-411. [CrossRef]

4. Gu, Y.; Li, Y.; Li, X.; Luo, P.; Wang, H.; Wang, X.; Wu, J.; Li, F. Energy Self-sufficient Wastewater Treatment Plants: Feasibilities and Challenges. Energy Procedia 2017, 105, 3741-3751. [CrossRef]

5. Wójtowicz, A.; Jędrzejewski, C.; Bieniowski, M.; Darul, H. Modelowe Rozwiąania w Gospodarce Osadowej; Izba Gospodarcza Wodociagi Polskie: Bydgoszcz, Poland, 2013.

6. Hao, X.; Liu, R.; Huang, X. Evaluation of the potential for operating carbon neutral WWTPs in China. Water Res. 2015, 87, 424-431. [CrossRef]

7. Christoforidou, P.; Bariamis, G.; Iosifidou, M.; Nikolaidou, E.; Samaras, P. Energy Benchmarking and Optimization of Wastewater Treatment Plants in Greece. Environ. Sci. Proc. 2020, 2, 36. [CrossRef]

8. Masłoń, A.; Czarnota, J.; Szaja, A.; Szulżyk-Cieplak, J.; Łagód, G. The Enhancement of Energy Efficiency in a Wastewater Treatment Plant through Sustainable Biogas Use: Case Study from Poland. Energies 2020, 13, 6056. [CrossRef]

9. Mainardis, M.; Magnolo, F.; Ferrara, C.; Vance, C.; Misson, G.; De Feo, G.; Speelman, S.; Murphy, F.; Goi, D. Alternative seagrass wrack management practices in the circular bioeconomy framework: A life cycle assessment approach. Sci. Total Environ. 2021, 798, 149283. [CrossRef] [PubMed]

10. Paul, S.; Dutta, A. Challenges and opportunities of lignocellulosic biomass for anaerobic digestion. Resour. Conserv. Recycl. 2018, 130, 164-174. [CrossRef]

11. Shen, Y.; Linville, J.; Leigh, U.; Demirtas, M.; Mintz, M.M.; Snyder, S.W. An Overview of Biogas Production and Utilization at Full-scale Wastewater Treatment Plants (WWTPs) in the United States: Challenges and Opportunities towards Energy-neutral WWTPs. United States. Renew. Sustain. Energy Rev. 2015, 50, 346-362. [CrossRef]

12. Hu, Y.; Bassi, A.; Xu, C. Energy from Biomass. In Future Energy: Improved, Sustainable and CleanOptions for our Planet, 3rd ed.; Letcher, T., Ed.; Elsevier: Amsterdam, The Netherlands, 2020; pp. 154-196. [CrossRef]

13. Appels, L.; Baeyens, J.; Degrève, J.; Dewil, R. Principles and potential of the anaerobic digestion of waste-activated sludge. Prog. Energy Combust. Sci. 2008, 34, 755-781. [CrossRef]

14. Iglesias, R.; Muñoz, R.; Polanco, M.; Díaz, I.; Susmozas, A.; Moreno, A.D.; Guirado, M.; Carreras, N.; Ballesteros, M. Biogas from Anaerobic Digestion as an Energy Vector: Current Upgrading Development. Energies 2021, 14, 2742. [CrossRef]

15. Siddique, M.N.; Wahid, Z.A. Achievements and perspectives of anaerobic co-digestion: A review. J. Clean. Prod. 2018, 194, 359-371. [CrossRef]

16. Mata-Alvarez, J.; Dosta, J.; Romero-Güiza, M.S.; Fonoll, X.; Peces, M.; Astals, S. A critical review on anaerobic co-digestion achievements between 2010 and 2013. Renew. Sustain. Energy Rev. 2014, 36, 412-427. [CrossRef]

17. Karki, R.; Chuenchart, W.; Surendra, K.C.; Shrestha, S.; Raskin, L.; Sung, S.; Hashimoto, A.; Kumar Khanal, S. Anaerobic co-digestion: Current status and perspectives. Bioresour. Technol. 2021, 330, 125001. [CrossRef] [PubMed]

18. Rabii, A.; Aldin, S.; Dahman, Y.; Elbeshbishy, E. A Review on Anaerobic Co-Digestion with a Focus on the Microbial Populations and the Effect of Multi-Stage Digester Configuration. Energies 2019, 12, 1106. [CrossRef]

19. El Ibrahimi, M.; Khay, I.; El Maakoul, A.; Bakhouya, M. Techno-economic and environmental assessment of anaerobic co-digestion plants under different energy scenarios: A case study in Morocco. Energy Convers. Manag. 2021, 245, 114553. [CrossRef]

20. Fernando-Foncillas, C.; Estevez, M.M.; Uellendahl, H.; Varrone, C. Co-Management of Sewage Sludge and Other Organic Wastes: A Scandinavian Case Study. Energies 2021, 14, 3411. [CrossRef]

21. Braun, R.; Wellinger, A. Potential of Co-Digestion; IEA: Paris, France, 2002

22. Chow, W.L.; Chong, S.; Lim, J.W.; Chan, Y.J.; Chong, M.F.; Tiong, T.J.; Chin, J.K.; Pan, G.-T. Anaerobic Co-Digestion of Wastewater Sludge: A Review of Potential Co-Substrates and Operating Factors for Improved Methane Yield. Processes 2020, 8, 39. [CrossRef]

23. Atelge, M.R.; Atabani, A.E.; Banu, J.R.; Krisa, D.; Kaya, M.; Eskicioglu, C.; Kumar, G.; Lee, C.; Yildiz, Y.S.; Unalan, S.; et al A critical review of pretreatment technologies to enhance anaerobic digestion and energy recovery. Fuel 2020, $270,117494$. [CrossRef]

24. Montusiewicz, A. Wspólfermentacja Osadów Ściekowych i Wybranych Kosubstratów Jako Metoda Efektywnej Biometanizacji; Politechnika Lubelska: Lublin, Poland, 2012.

25. Zaborowska, E.; Majtacz, J.; Drewnowski, J.; Sobotka, D.; Al-Hazmi, H.; Kowal, P.; Makinia, J. Improving the energy balance in wastewater treatment plants by optimization of aeration control and application of new technologies. In Water Supply and Wastewater Disposal; Sobczuk, H., Kowalska, B., Eds.; LUT: Lublin, Poland, 2018; pp. 317-328.

26. Asteriadis, I.; Azis, K.; Ntougias, S.; Melidis, P. A control strategy for an intermittently aerated and fed bioreactor to reduce aeration costs: A simulation study. Biochem. Eng. J. 2021, 173. [CrossRef]

27. Izadi, P.; Eldyasti, A. Enhancement of simultaneous nitrogen and phosphorus removal using intermittent aeration mechanism. J. Environ. Sci. 2021, 109, 1-14. [CrossRef] 
28. Chen, Y.; Cheng, J.J.; Creamer, K.S. Inhibition of anaerobic digestion process: A review. Bioresour. Technol. 2008, 99, 4044-4064. [CrossRef] [PubMed]

29. Sankaran, K.; Premalatha, M.; Vijayasekaran, M.; Somasundaram, V.T. DEPHY project: Distillery wastewater treatment through anaerobic digestion and phycoremediation-A green industrial approach. Renew. Sustain. Energy Rev. 2014, 17, 634-643. [CrossRef]

30. Chowdhary, P.; Raj, A.; Bharagava, R.N. Environmental pollution and health hazards from distillery wastewater and treatment approaches to combat the environmental threats: A review. Chemosphere 2018, 194, 229-246. [CrossRef]

31. Mohana, S.; Acharya, B.K.; Madamwar, D. Distillery spent wash: Treatment technologies and potential applications. J. Hazard. Mater. 2009, 163, 12-25. [CrossRef] [PubMed]

32. Gunes, B.; Stokes, J.; Davis, P.; Connolly, C.; Lawler, J. Pre-treatments to enhance biogas yield and quality from anaerobic digestion of whiskey distillery and brewery wastes: A review. Renew. Sustain. Energy Rev. 2019, 113, 109281. [CrossRef]

33. Bala, R.; Gupta, G.K.; Dasgupta, B.V.; Mondal, M.K. Pretreatment optimisation and kinetics of batch anaerobic digestion of liquidised OFMSW treated with NaOH: Models verification with experimental data. J. Environ. Manag. 2019, 237, 313-321. [CrossRef]

34. American Public Health Association (APHA). Standard Methods for the Examination of Water and Wastewater, 22nd ed.; APHA: Washington, DC, USA, 2012.

35. Tyagi, V.; Fdez-Güelfo, L.A.; Zhou, Y.; Álvarez-Gallego, C.; García, L.I.; Ng, W. Anaerobic co-digestion of organic fraction of municipal solid waste (OFMSW): Progress and challenges. Renew. Sustain. Energy Rev. 2018, 93, 380-399. [CrossRef]

36. Jain, S.; Jain, S.; Wolf, I.T.; Lee, J.; Tong, Y.W. A comprehensive review on operating parameters and different pretreatment methodologies for anaerobic digestion of municipal solid waste. Renew. Sustain. Energy Rev. 2015, 52, 142-154. [CrossRef]

37. Zhang, J.; Lv, C.; Tong, J.; Liu, J.; Liu, J.; Yu, D.; Wang, Y.; Chen, M.; Wei, Y. Optimization and microbial community analysis of anaerobic co-digestion of food waste and sewage sludge based on microwave pretreatment. Bioresour. Technol. 2016, 200, $253-261$. [CrossRef]

38. Ahmed, B.; Tyagi, V.K.; Aboudi, K.; Naseem, A.; Alvarez-Gallego, C.J.; Fernandez-Guelfo, L.A.; Kazmi, A.A.; Romero-Garcia, L.I. Thermally enhanced solubilization and anaerobic digestion of organic fraction of municipal solid waste. Chemosphere 2021, 282, 131136. [CrossRef]

39. Ripoll, V.; Agabo-García, C.; Perez, M.; Solera, R. Improvement of biomethane potential of sewage sludge anaerobic co-digestion by addition of "sherry-wine" distillery wastewater. J. Clean. Prod. 2020, 251, 119667. [CrossRef]

40. Ansari, F.A.; Singh, D.P.; Khan, A.H.; Kisku, G.C.; Ashquin, M.; Ahmad; Yunus, G.M.; Rahman, Q. Physico-chemical characteristics of spentwash of distillery industry. Pollut. Res. 2008, 27, 125-127.

41. Nagao, N.; Tajima, N.; Kawai, M.; Niwa, C.; Kurosawa, N.; Matsuyama, T.; Yusoff, F.M.; Toda, T. Maximum organic loading rate for the single-stage wet anaerobicdigestion of food waste. Bioresour. Technol. 2012, 118, 210-218. [CrossRef]

42. Di Maria, F.; Sordi, A.; Cirulli, G.; Micale, C. Amount of energy recoverable from anexisting sludge digester with the co-digestion with fruit and vegetable waste at reduced retention time. Appl. Energ. 2015, 150, 9-14. [CrossRef]

43. Dareioti, M.A.; Kornaros, M. Anaerobic mesophilic co-digestion of ensiled sorghum, cheese whey and liquid cow manure in a two-stage CSTR system: Effect of hydraulic retention time. Bioresour. Technol. 2015, 175, 553-556. [CrossRef] [PubMed]

44. Li, L.; He, Q.; Ma, Y.; Wang, X.; Peng, X. Dynamics of microbial community in a mesophilic anaerobic digester treating food waste: Relationship between community structure and processs tability. Bioresour. Technol. 2015, 189, 113-120. [CrossRef] [PubMed]

45. Madsen, M.; Holm-Nielsen, J.B.; Esbensen, K.H. Monitoring of anaerobic digestion processes: A review perspective. Renew. Sustain. Energy Rev. 2011, 15, 3141-3155. [CrossRef]

46. Khakbaz, A.; De Nobili, M.; Mainardis, M.; Contin, M.; Aneggi, E.; Mattiussi, M.; Cabras, I.; Busut, M.; Goi, D. Monitoring of heavy metals, EOX and LAS in sewage sludge for agricultural use: A case study. Detritus 2020, 12, 160-168. [CrossRef]

47. Grosser, A. Determination of methane potential of mixtures composed of sewage sludge, organic fraction of municipal waste and grease trap sludge using biochemical methane potential assays. A comparison of BMP tests and semi-continuous trial results. Energy 2018, 143, 488-499. [CrossRef]

48. Szaja, A.; Montusiewicz, A. Enhancing the co-digestion efficiency of sewage sludge and cheese whey using brewery spent grain as an additional substrate. Bioresour. Technol. 2019, 291, 1-9. [CrossRef] 